\title{
CDISC SDTM ECG Test Name Terminology
}

National Cancer Institute

\section{Source}

National Cancer Institute. CDISC SDTM ECG Test Name Terminology. NCI Thesaurus.

Code C71152.

Terminology codelist used with ECG Test Names within the Clinical Data Interchange Standards Consortium Study Data Tabulation Model. 